\title{
Estimation of Reference Evapotranspiration (ETo) and Crop Water Requirement of Major Kharif Cereals of Marathwada Region, Maharashtra
}

\author{
S.V. Phad*, K.K. Dakhore and R.S. Sayyad \\ Department of Agricultural Meteorology, Vasantrao Naik Marathwada Krishi Vidyapeeth, \\ Parbhani 431 402, Maharashtra, India \\ *Corresponding author
}

\begin{tabular}{|l|}
\hline K e y w o r d s \\
$\begin{array}{l}\text { Evapotranspiration } \\
\text { (ETo) and Crop } \\
\text { Water, } \\
\text { Kharif Cereals }\end{array}$ \\
\hline Article Info \\
\hline $\begin{array}{l}\text { Accepted: } \\
\text { 18 January } 2019 \\
\text { Available Online: } \\
\text { 10 February } 2019\end{array}$ \\
\hline
\end{tabular}

\section{Introduction}

Water is one of the most essential natural resource which plays a vital role in maintaining biodiversity, our health, social welfare and our economic development (Donald, 1968).

\section{A B S T R A C T}

The reference evapotranspiration (ETo) is an important agrometeorological parameter which has been used in a number of applications. In present study daily ETo was determined for seven districts of Marathwada region having long period (29-35 years) weather data by Hargreaves method. The Kc values for kharif sorghum, maize and pearlmillet as given in FAO-56 paper was used to calculate the daily crop water requirement $(\mathrm{ETc})$. The results revealed that, ETo reaches to its peak value during $28^{\text {th }}$ April to $18^{\text {th }}$ May at all the districts of marathwada region. Among the districts, Parbhani had highest ETo and Aurangabad had lowest ETo followed by Nanded, Latur, Osmanabad, Beed and Jalna. The mean water requirement (ETc) of kharif sorghum during initial stage was found to be lower (1.83 to $2.0 \mathrm{~mm} \mathrm{day}^{-1}$ ) and it increased during developmental stage (3.34 to $3.70 \mathrm{~mm} \mathrm{day}{ }^{-1}$ ) and during mid season stage $\left(4.70\right.$ to $5.10 \mathrm{~mm}$ day $^{-1}$ ) and decreased during late-season stage (2.91 to $\left.3.13 \mathrm{~mm} \mathrm{day}^{-1}\right)$. The total water requirement across the districts varies between Parbhani (436.04 mm) to Aurangabad (399.42 mm). The mean water requirement of kharif maize during initial stage (1.59 to $\left.1.74 \mathrm{~mm} \mathrm{day}^{-1}\right)$, during developmental stage (2.77 to $3.08 \mathrm{~mm} \mathrm{day}^{-1}$ ), during mid season stage (5.07 to 5.54 $\mathrm{mm}$ day $^{-1}$ ) and during late season stage it decreases (1.55 to $\left.1.67 \mathrm{~mm} \mathrm{day}^{-1}\right)$. The total water requirement of kharif maize varies between Parbhani $(373.13 \mathrm{~mm})$ and Aurangabad (340.74 mm). The mean water requirement of kharif pearlmillet during initial stage (1.85 to $\left.2.03 \mathrm{~mm} \mathrm{day}^{-1}\right)$, during developmental stage $\left(2.82\right.$ to $\left.3.13 \mathrm{~mm} \mathrm{day}^{-1}\right)$, during mid season stage (4.21 to $4.64 \mathrm{~mm} \mathrm{day}^{-1}$ ) and during late season stage it decreases (1.29 to $1.38 \mathrm{~mm}$ day $\left.^{-1}\right)$. The total water requirement of kharif pearlmillet varies between Parbhani (291.69 $\mathrm{mm}$ ) and Aurangabad (265.02 mm). 
extended surface of 8-12 $\mathrm{cm}$ tall green grass cover, usually a well-watered, actively growing and completely shading the ground. The prediction of evapotranspiration is based on meteorological variables like temperature, humidity, sunshine hour, wind speed. By applying a crop coefficient $(\mathrm{Kc})$ values, this ETo can be used to estimate the crop evapotranspiration (ETc), (Doorenbos and Pruitt, 1975). The adoption of exact or correct amount of water and correct timing of application is very essential for scheduling irrigations to meet the crop's water use demands and for optimum crop production. Estimation of crop water requirements (ETc) is one of the main components used in irrigation planning, design and operation (Rowshon et al., 2013). Jensen et al., (1990), provided detailed reviews of the methods commonly used to determine evapotranspiration and estimated crop water requirements.

In this paper attempt has been made to determine reference evapotranspiration (ETo)) and crop water requirement (ETc) of major kharif cereals (Sorghum, Maize and Pearlmillet) using long period weather data (1982-2017) of different districts of Marathwada region.

\section{Materials and Methods}

\section{Location of study area}

The Marathwada region of Maharashtra states comprises of eight districts total area of 64818 sq $\mathrm{km}$ geographically lies between $17^{\circ} 35^{\prime}$ to $20^{\circ} 40^{\prime}$ latitude and $74^{\circ} 40^{\prime}$ to $78^{\circ} 10^{\prime}$ longitude. The altitude ranges between 300 and 900 meter above mean sea level (MSL). The present study is conformed to Marathwada region comprising of 8 districts with total geographical area is 64.5 lakh ha with 57.0 lakh ha land suitable for agriculture. Table 1 shows detailed information of different districts of Marathwada Region

\section{Collection and processing of meteorological data}

Daily weather data of maximum and minimum temperature of selected districts for at least 29 to 35 years period was collected from India Meteorological Department (IMD), Pune. The collected data of each district were used to work out mean of each parameter of each district and then those daily mean data used to calculate reference evapotranspiration (ETo). The daily crop water requirement $(\mathrm{ETc})$ was determined by multiplying daily ETo of each districts with Kc, determined for each crop. Thus daily ETc computed were summed for different growth stages of crop and total seasonal crop water was determined.

\section{Estimation of reference evapotranspiration (ETo)}

\section{Hargreaves method}

Hargreaves developed a method in 1985 to estimate evapotranspiration is an empirical relation based on air temperature and radiation. (Basanagouda, 2016). The Hargreaves method is given by:

ETo $=0.0023 \mathrm{R}_{\mathrm{A}} \mathrm{T}_{\mathrm{d}}^{0.5}\left(\mathrm{~T}_{\mathrm{m}}+17.8\right)$

Where, ETo is reference evapotranspiration $\left(\mathrm{mm}\right.$ day $\left.^{-1}\right)$

$\mathrm{R}_{\mathrm{A}}$ is extra-terrestrial radiation $\left(\mathrm{mm} \mathrm{day}{ }^{-1}\right.$ )

$\mathrm{T}_{\mathrm{d}}$ is difference between maximum and minimum temperature $\left({ }^{\circ} \mathrm{C}\right)$

$\mathrm{T}_{\mathrm{m}}$ is mean temperature $\left({ }^{\circ} \mathrm{C}\right)$

\section{Crop evapotranspiration/crop water requirement (ETc)}

The amount of water required to compensate the evapotranspiration loss from the cropped field is defined as crop water requirement. The crop evapotranspiration differs distinctly 
from the reference evapotranspiration (ETo) as the ground cover, canopy properties and aerodynamic resistance of the crop are different from grass.

$\mathrm{ETc}=\mathrm{Kc}^{\times}$ETo

Where,

ETc = crop evapotranspiration/Crop water requirement, $\left(\mathrm{mm} \mathrm{day}^{-1}\right)$,

ETo $=$ reference evapotranspiration, $(\mathrm{mm}$ day $\left.{ }^{1}\right)$,

$\mathrm{Kc}=$ crop coefficient.

The total duration of these crops were divided into four growth stages initial, developmental, mid-season and late-season. The initial stage refers to the germination and early growth stage when the soil surface is not or is hardly covered by the crop. The crop development stage is the stage from the end of the initial stage to attainment of effective full ground cover (groundcover 70-80\%). The mid-season stage is the stage from attainment of effective full groundcover to the start of maturity, as indicated by discolouring of leaves or falling of leaves. The late season stage runs from the start of maturity to harvest or full senescence. Table 2 shows FAO crop coefficients (Kc) values and Table 3 shows Crops, their season and length of crop growth stages for various Sowing periods (days).

\section{Results and Discussion}

\section{Reference evapotranspiration (ETo) for Marathwada region}

\section{Variation of ETo on daily basis}

The daily variation of ETo for seven districts of marathwada region observed that there is large fluctuation in daily ETo at different districts of marathwada region. Although the daily ETo increases continuously from January and reaches to its maximum during
May, but there is quite differences among the districts. The ETo reaches to its peak value during $28^{\text {th }}$ April to $18^{\text {th }}$ May at all the districts of marathwada region. During June ETo decreases sharply and remains low during July and August and with slight increase during month of September, it decreases afterwards (Fig. 1). The Hargreaves method shows, range of ETo was found highest at Parbhani $3.81 \mathrm{~mm} \mathrm{day}^{-1}\left(26^{\text {th }} \mathrm{Dec}\right)$ to $7.84 \mathrm{~mm} \mathrm{day}^{-1}\left(30^{\text {th }}\right.$ April $)$ with mean annual value of $5.39 \mathrm{~mm} \mathrm{day}^{-1}$ and lowest at Aurangabad $3.67 \mathrm{~mm} \mathrm{day}^{-1}\left(28^{\text {th }}\right.$ and $29^{\text {th }}$ Dec) to $7.28 \mathrm{~mm} \mathrm{day}^{-1}\left(27^{\text {th }}\right.$ and $28^{\text {th }}$ April), with mean annual value of $5.04 \mathrm{~mm} \mathrm{day}^{-1}$ as compared to rest of the districts. (Table 4) (Mehta R. (2015)

\section{Crop Evapotranspiration/Crop Water Requirement (ETc)}

\section{ETc of Kharif Sorghum}

The daily ETc of sorghum determined for seven districts along with the mean values by Hargreaves method revealed that,. During initial stage of crop, total water requirement in region varies between 36.59 to $40.09 \mathrm{~mm}$ with mean water requirement varies between 1.83 to $2.0 \mathrm{~mm} \mathrm{day}^{-1}$, During developmental stage of crop, total water requirement in region varies between 116.75 to $129.65 \mathrm{~mm}$ with mean water requirement varies between 3.34 to $3.70 \mathrm{~mm} \mathrm{day}^{-1}$, During the mid stage of crop, total water requirement in region varies between 187.95 to $203.84 \mathrm{~mm}$ with mean water requirement varies between 4.70 to $5.10 \mathrm{~mm} \mathrm{day}^{-1}$, During the late-season stage of crop, total water requirement in region varies between 55.23 to $59.51 \mathrm{~mm}$ with mean water requirement varies between 2.91 to $3.13 \mathrm{~mm} \mathrm{day}^{-1}$. It is found from above discussion that the variation in ETc is more at developmental and mid-season stages as compared to initial and maturity stages of the sorghum crop across the districts. Among the 
different districts, the highest ETc is observed at Parbhani (436.04 mm) while the lowest value is at Aurangabad (399.42 mm) followed Jalna (411.27 mm), Nanded (430.78 mm), Osmanabad (423.73 mm), Latur (417.21 mm), Beed (418.02 mm). (Table 5) (Chavan M.L., 2009)

\section{ETc of Kharif maize}

The daily ETc of maize determined for seven districts along with the mean values by Hargreaves method revealed that During initial stage of crop, total water requirement in region varies between 23.84 to $26.08 \mathrm{~mm}$ with mean water requirement varies between 1.59 to $1.74 \mathrm{~mm} \mathrm{day}^{-1}$, During developmental stage of crop, total water requirement in region varies between 82.98 to $92.28 \mathrm{~mm}$ with mean water requirement varies between
2.77 to $3.08 \mathrm{~mm} \mathrm{day}^{-1}$, During the mid stage of crop, total water requirement in region varies between 202.90 to $221.79 \mathrm{~mm}$ with mean water requirement varies between 5.07 to $5.54 \mathrm{~mm} \mathrm{day}^{-1}$, During the late-season stage of crop, total water requirement in region varies between 31.03 to $33.40 \mathrm{~mm}$ with mean water requirement varies between 1.55 to $1.67 \mathrm{~mm} \mathrm{day}^{-1}$. It is found from above discussion that the variation in ETc is more at developmental and mid-season stages as compared to initial and maturity stages of the sorghum crop across the districts. Among the different districts, the highest ETc is observed at Parbhani $(373.13 \mathrm{~mm})$ while the lowest value is at Aurangabad (340.74 mm) followed Jalna (351.94 mm), Nanded (370.32 mm), Osmanabad (364.22 mm), Latur (357.79 mm), Beed (360.62 mm). (Table 6) (Chavan, 2009).

Table.1 Detailed information of different districts of Marathwada Region

\begin{tabular}{|l|c|c|c|c|}
\hline \multicolumn{1}{|c|}{ Districts } & Latitude & Longitude & Altitude(m) & $\begin{array}{c}\text { Data } \\
\text { Availability }\end{array}$ \\
\hline PARBHANI & $19^{\circ} 16^{\prime}$ & $76^{\circ} 46^{\prime}$ & 423.50 & $1982-2017$ \\
\hline AURANGABAD & $19^{\circ} 51^{\prime}$ & $75^{\circ} 24^{\prime}$ & 586.60 & $1982-2010$ \\
\hline JALNA & $19^{\circ} 50^{\prime}$ & $75^{\circ} 48^{\prime}$ & 534.00 & $1982-2010$ \\
\hline NANDED & $19^{\circ} 05^{\prime}$ & $77^{\circ} 20^{\prime}$ & 358.40 & $1982-2010$ \\
\hline OSMANABAD & $18^{\circ} 10^{\prime}$ & $76^{\circ} 03^{\prime}$ & 662.89 & $1982-2010$ \\
\hline LATUR & $18^{\circ} 04^{\prime}$ & $77^{\circ} 07^{\prime}$ & 639.80 & $1982-2010$ \\
\hline BEED & $19^{\circ} 00^{\prime}$ & $75^{\circ} 43^{\prime}$ & 519.00 & $1982-2010$ \\
\hline
\end{tabular}

Table.2 FAO crop coefficients $(\mathrm{Kc})$ for non stressed, well-managed crops in semi-arid climates $\left(\mathrm{RH}_{\min }=45 \%, \mathrm{u}_{2}=2 \mathrm{~m} \mathrm{~s}^{-1}\right)$ (Source: FAO-56 Allen et al., 1998)

\begin{tabular}{|l|c|c|c|}
\hline \multicolumn{1}{|c|}{ Kharif Cereals } & Kc $_{\text {ini }}$ & Kc $_{\text {mid }}$ & Kc $_{\text {end }}$ \\
\hline Sorghum & 0.35 & 1.10 & 0.65 \\
\hline Maize & 0.30 & 1.20 & 0.35 \\
\hline Pearl millet & 0.35 & 1.00 & 0.30 \\
\hline
\end{tabular}


Table.3 Crops, their season and length of crop growth stages for various Sowing periods (days)

\begin{tabular}{|c|c|c|c|c|c|c|c|}
\hline \multirow{2}{*}{$\begin{array}{l}\text { Sr. } \\
\text { No. }\end{array}$} & \multirow[t]{2}{*}{ Crops } & \multirow[t]{2}{*}{ Season } & \multicolumn{4}{|c|}{ Length of growth stages (days) } & \multirow[b]{2}{*}{ Sowi } \\
\hline & & & Initial & Developmental & Mid-season & Late-season & \\
\hline 1 & Sorghum & Kharif & 15 & 30 & 40 & 20 & $15-\mathrm{Ju}$ \\
\hline 2 & Maize & Kharif & 15 & 30 & 40 & 20 & $15-\mathrm{Ju}$ \\
\hline 3 & Pearlmillet & Kharif & 15 & 25 & 35 & 15 & $15-\mathrm{Ju}$ \\
\hline \multicolumn{8}{|c|}{ Table.4 Ranges of daily ETo $\left(\mathrm{mm} \mathrm{day}^{-1}\right)$ by Hargreaves method at different districts of Marathwada } \\
\hline & \multicolumn{2}{|c|}{ District } & \multicolumn{2}{|r|}{ Max } & Min & \multicolumn{2}{|l|}{ Mean } \\
\hline & \multicolumn{2}{|c|}{ PARBHANI } & \multicolumn{2}{|r|}{7.84} & 3.81 & \multicolumn{2}{|l|}{5.39} \\
\hline & \multicolumn{2}{|c|}{ AURANGABAD } & \multicolumn{2}{|r|}{7.28} & 3.67 & \multicolumn{2}{|l|}{5.04} \\
\hline & \multicolumn{2}{|c|}{ JALNA } & \multicolumn{2}{|r|}{7.79} & 3.59 & \multicolumn{2}{|l|}{5.08} \\
\hline & \multicolumn{2}{|c|}{ NANDED } & \multicolumn{2}{|r|}{7.72} & 3.69 & \multicolumn{2}{|l|}{5.22} \\
\hline & \multicolumn{2}{|c|}{ OSMANABAD } & \multicolumn{2}{|r|}{7.32} & 3.82 & \multicolumn{2}{|l|}{5.15} \\
\hline & \multicolumn{2}{|c|}{ LATUR } & \multicolumn{2}{|r|}{7.71} & 3.64 & \multicolumn{2}{|l|}{5.18} \\
\hline & \multicolumn{2}{|c|}{ BEED } & & 7.62 & 3.59 & 5.12 & \\
\hline
\end{tabular}

Table.5 ETc of kharif sorghum by Hargreaves method at different districts of Marathwada region

\begin{tabular}{|c|c|c|c|c|c|c|c|c|c|}
\hline \multirow{2}{*}{ District } & \multicolumn{2}{|c|}{ Initial Stage } & \multicolumn{2}{c|}{ Developmental Stage } & \multicolumn{2}{c|}{ Mid-Season Stage } & \multicolumn{2}{c|}{ Late-Season Stage } \\
\cline { 2 - 9 } & Total & Mean & Total & Mean & Total & Mean & Total & Mean \\
\hline PARBHANI & 40.09 & 2.00 & 129.65 & 3.70 & 203.67 & 5.09 & 59.51 & 3.13 & 436.04 \\
\hline AURANGABAD & 36.59 & 1.83 & 116.75 & 3.34 & 187.95 & 4.70 & 55.23 & 2.91 & 399.42 \\
\hline JALNA & 36.96 & 1.85 & 119.22 & 3.41 & 196.65 & 4.92 & 55.53 & 2.92 & 411.27 \\
\hline NANDED & 39.60 & 1.98 & 127.98 & 3.66 & 203.19 & 5.08 & 57.04 & 3.00 & 430.78 \\
\hline OSMANABAD & 36.91 & 1.85 & 123.17 & 3.52 & 203.84 & 5.10 & 56.83 & 2.99 & 423.73 \\
\hline LATUR & 39.21 & 1.96 & 124.88 & 3.57 & 194.60 & 4.86 & 55.59 & 2.93 & 417.21 \\
\hline BEED & 38.93 & 1.95 & 124.22 & 3.55 & 196.77 & 4.92 & 55.26 & 2.91 & 418.02 \\
\hline
\end{tabular}


Table.6 ETc of kharif maize by Hargreaves method at different districts of Marathwada region

\begin{tabular}{|c|c|c|c|c|c|c|c|c|c|}
\hline \multirow{2}{*}{ District } & \multicolumn{2}{|c|}{ Initial Stage } & \multicolumn{2}{|c|}{ Developmental Stage } & \multicolumn{2}{c|}{ Mid-Season Stage } & \multicolumn{2}{c|}{ Late-Season Stage } & \multicolumn{2}{c|}{ Total } \\
\cline { 2 - 9 } & Total & Mean & Total & Mean & Total & Mean & Total & Mean \\
\hline PARBHANI & 26.08 & 1.74 & 92.28 & 3.08 & 221.37 & 5.53 & 33.40 & 1.67 & 373.13 \\
\hline AURANGABAD & 23.84 & 1.59 & 82.98 & 2.77 & 202.90 & 5.07 & 31.03 & 1.55 & 340.74 \\
\hline JALNA & 23.99 & 1.60 & 85.02 & 2.83 & 211.68 & 5.29 & 31.26 & 1.56 & 351.94 \\
\hline NANDED & 25.66 & 1.71 & 91.90 & 3.06 & 220.63 & 5.52 & 32.14 & 1.61 & 370.32 \\
\hline OSMANABAD & 23.98 & 1.60 & 86.45 & 2.88 & 221.79 & 5.54 & 32.01 & 1.60 & 364.22 \\
\hline LATUR & 25.52 & 1.70 & 89.73 & 2.99 & 211.26 & 5.28 & 31.28 & 1.56 & 357.79 \\
\hline BEED & 25.31 & 1.69 & 87.88 & 2.93 & 215.96 & 5.40 & 31.46 & 1.57 & 360.62 \\
\hline
\end{tabular}

Table.7 ETc of kharif pearlmillet by Hargreaves method at different districts of Marathwada region

\begin{tabular}{|c|c|c|c|c|c|c|c|c|c|}
\hline \multirow{2}{*}{ District } & \multicolumn{2}{|c|}{ Initial Stage } & \multicolumn{2}{|c|}{ Developmental Stage } & \multicolumn{2}{|c|}{ Mid-Season Stage } & \multicolumn{2}{c|}{ Late-Season Stage } \\
\cline { 2 - 9 } & Total & Mean & Total & Mean & Total & Mean & Total & Mean \\
\hline PARBHANI & 30.42 & 2.03 & 81.16 & 3.12 & 162.47 & 4.64 & 20.76 & 1.38 & 291.69 \\
\hline AURANGABAD & 27.81 & 1.85 & 73.21 & 2.82 & 147.48 & 4.21 & 19.33 & 1.29 & 265.02 \\
\hline JALNA & 27.98 & 1.87 & 74.62 & 2.87 & 153.31 & 4.38 & 20.28 & 1.35 & 273.33 \\
\hline NANDED & 29.93 & 2.00 & 81.32 & 3.13 & 160.66 & 4.59 & 20.68 & 1.38 & 289.46 \\
\hline OSMANABAD & 27.97 & 1.86 & 75.61 & 2.91 & 161.73 & 4.62 & 20.76 & 1.38 & 283.16 \\
\hline LATUR & 29.78 & 1.99 & 79.24 & 3.05 & 154.33 & 4.41 & 19.95 & 1.33 \\
\hline BEED & 29.53 & 1.97 & 77.07 & 2.96 & 158.40 & 4.53 & 20.08 & 1.34 & 282.11 \\
\hline
\end{tabular}


Fig.1 Daily variation of ETo $\left(\mathrm{mm} \mathrm{day}^{-1}\right)$ by Hargreaves method at different districts of Marathwada region

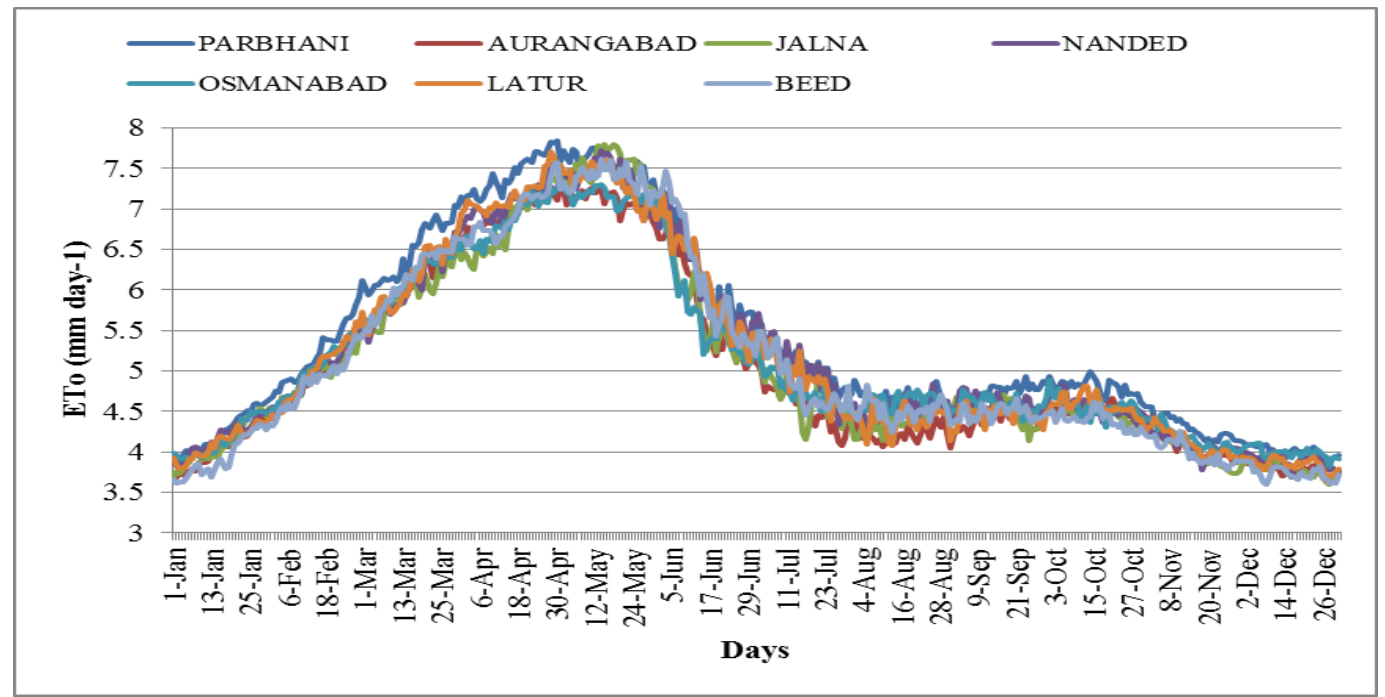

\section{ETc of Kharif Pearlmillet}

The daily ETc of pearlmillet determined for seven districts along with the mean values by Hargreaves method revealed that, During initial stage of crop, total water requirement in region varies between 27.81 to $30.42 \mathrm{~mm}$ with mean water requirement varies between 1.85 to $2.03 \mathrm{~mm}$ day $^{-1}$, During developmental stage of crop, total water requirement in region varies between 73.21 to $81.32 \mathrm{~mm}$ with mean water requirement varies between 2.82 to $3.13 \mathrm{~mm} \mathrm{day}^{-1}$, During the mid stage of crop, total water requirement in region varies between 147.48 to $162.47 \mathrm{~mm}$ with mean water requirement varies between 4.21 to $4.64 \mathrm{~mm} \mathrm{day}^{-1}$, During the late-season stage of crop, total water requirement in region varies between 19.33 to $20.76 \mathrm{~mm}$ with mean water requirement varies between 1.29 to $1.38 \mathrm{~mm}$ day $^{-1}$. It is found from above discussion that the variation in ETc is more at developmental and mid-season stages as compared to initial and maturity stages of the sorghum crop across the districts. Among the different districts, the highest ETc is observed at Parbhani (291.69 mm) while the lowest value is at Aurangabad $(265.02 \mathrm{~mm})$ followed Jalna $(273.33 \mathrm{~mm})$, Nanded (289.46 mm), Osmanabad (283.16 $\mathrm{mm})$, Latur (280.25 mm), Beed (282.11 mm) (Table 7) (Chavan, 2009).

It is concluded that, ETo increases continuously from January and reaches to its maximum during May then in the month of June ETo decreases sharply and remains low during July and August and with slight increase in the month of September, it decreases afterwards. In summer season when the temperature and wind speed both are highest so the total ETo was maximum, while in kharif season there may be wind speed is high but temperature comparatively lower than the summer due to rainfall thereby less ETo. Among the districts Parbhani had highest ETo and Aurangabad had lowest ETo followed by Nanded, Latur, Osmanabad, Beed and Jalna. The crop water requirement $(\mathrm{ETc})$ of major kharif cereals was found to vary not only with the crops it's stage and duration, but also with the season as well. During initial stage of the crops, the ETc was less and increased during development stage, reached to its maximum 
values during mid season and reduced during crop maturation stages. Among the districts, crop water requirement for major kharif cereals found highest at Parbhani and lowest at Aurangabad followed by Nanded, Latur, Osmanabad, Beed and Jalna.

\section{References}

Allen, R. G., Pereira, L. S., Raes, D. and Smith, M. 1998. Crop Evapotranspiration: Guidelines for computing crop water requirements. Irrigation and Drainage Paper 56, Food and Agriculture Organization of the United Nations, Rome. pp. 300 .

Basanagouda R.F. and Suresh J. H., 2016. Identification of suitable method for crop assessment by estimating evapotranspiration-a case study, International Journal Of Agricultural Sciences, 8 (48): 2020-2023.

Chavan M.L., U.M. Khodke and N.M. Changade. 2009. Estimation of crop water requirement for irrigation planning in a semi arid region. International Journal of Agricultural
Engineering, 2 (2): 236-242.

Donald, B. A. 1968. Water - Our second most important natural resource, 9 B.C.L. revised. 19 (3): 535-552.

Doorenbos, J. and Pruitt, W. O. 1975. Guidelines for predicting crop water requirements, Irrigation and Drainage Paper 24, FAO of the United Nations, Rome. pp. 179.

Jensen, M. E., Burman, R. D. and Allen, R. G. 1990. Evapotranspiration and irrigation water requirements. Irrig. Drainage Div. American Society Civil Engineers, NY, 5 (1): 45-48.

Mehta R. 2015. Estimation of reference evapotranspiration and determination of crop water requirement of major crops of Gujarat. M.Sc Agri. Thesis submitted to the B. A. College of Agriculture, Anand Agricultural University, Anand-388 110 (Gujarat).

Rowshon, M. K., Amin, M. S. M., Mojid, M. and Yaji, M. 2013. Estimated evapotranspiration of rice based on pan evaporation as a surrogate to lysimeter measurement. Paddy Water Environment. 13 (4): 356-364.

\section{How to cite this article:}

Phad, S.V., K.K. Dakhore and Sayyad, R.S. 2019. Estimation of Reference Evapotranspiration (ETo) and Crop Water Requirement of Major Kharif Cereals of Marathwada Region, Maharashtra. Int.J.Curr.Microbiol.App.Sci. 8(02): 2441-2448. doi: https://doi.org/10.20546/ijcmas.2019.802.284 